\title{
Masterly deceptions brought to light
}

\section{Even the most prestigious art gallery has a few sham pictures in its collection, and scientific techniques are increasingly able to uncover them, as Daniel Cressey finds out.}

Close Examination: Fakes, Mistakes and
Discoveries
National Gallery, London
30 June- 12 September

Since its founding in 1934, the science laboratory of London's National Gallery has thrown light — visible, infrared, X-ray and metaphori$\mathrm{cal}$ - on hundreds of artworks, including rare paintings by Albrecht Dürer, Sandro Botticelli and Raphael. This has proved embarrassing as well as illuminating: some of the pieces in the gallery's collection have been uncovered as fakes.

The work of the gallery's conservation scientists is the subject of a major exhibition there this summer. Close Examination highlights the analyses of dozens of pictures dating from the fifteenth to the twentieth century, exposing instances of deception, modification and redemption.

Dating techniques unearthed some imitations. Tree-ring analysis, for instance, constrains the age of wood panels on which works are daubed. An example is a portrait of Edzard the Great, Count of East Friesland in Germany. The picture was thought to hail from the sixteenth century, but the wood on which it was painted was dated to around the eighteenth century.

When suspicions about a painting's veracity are raised, perhaps by incongruous costumes or other unusual stylistic features, the full battery of scientific tests is wheeled out. Chemical analysis of tiny paint samples can be definitive. A supposedly fifteenth-century group portrait purchased by the gallery in 1923 was exposed as a forgery when it was found to contain pigments that were not used before the nineteenth century.

The finds revealed by the conservators inform the history of art. The inclusion of the synthetic blue-green pigment viridian in a landscape by Jean-Baptiste-Camille Corot, The Roman Campagna, with the Claudian Aqueduct (1826), raised questions about that picture's authenticity.

The pigment was thought to have been available only in the late 1830 s, yet accurate dating confirmed that the painting was indeed produced in 1826. The answer to this puzzle lay in one Parisian art supplier, frequented by Corot, who made viridian available to the artist earlier.

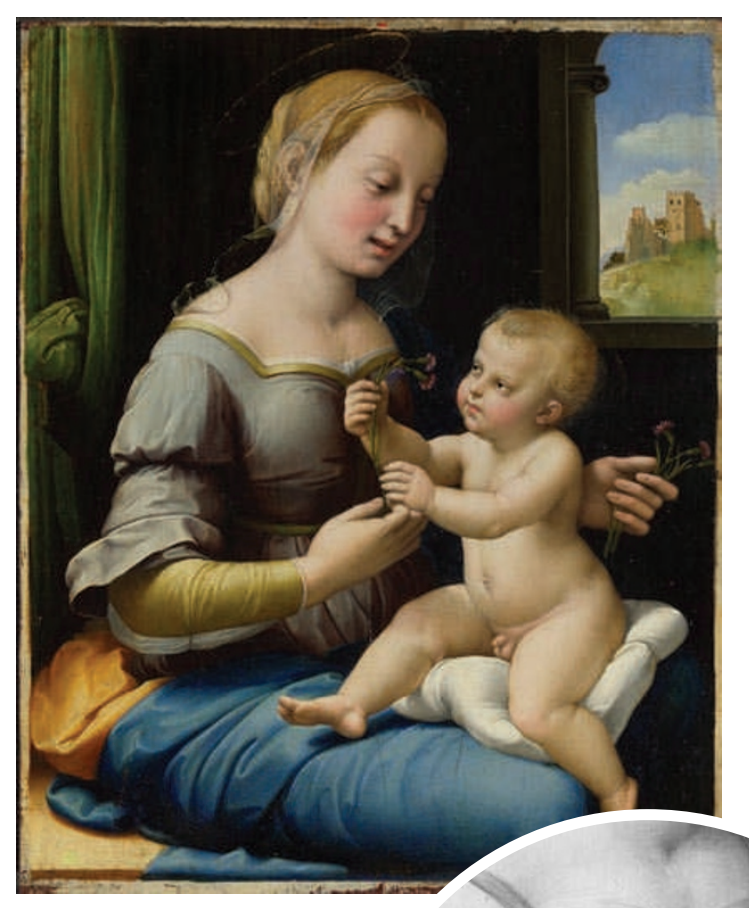

National Gallery's version, featured in the exhibition, reveals a detailed underdrawing of the work. Such reworking has been found to be common in Friedrich's paintings, but is absent from the Dortmund canvas. This suggests that the National Gallery holds the original piece.

A similar analysis settled the long-standing controversy over who painted The Madonna of the Pinks, bought by the gallery in 2004 for $£ 22$ million (US $\$ 40$ million at the time). As far back as 1835, an expert publicly questioned whether this was a work by Raphael, and the debate has raged ever since. The infrared view shows that the artist made changes and modifications, in vastly more detail than a forger would mimic. Paint samples included rare pigments not used after Raphael's time. On this basis, Roy last month proclaimed The Madonna of the Pinks to Infrared scans (inset) of The Madonna of the Pinks reveal that it is Raphael's work.

With these scientific tools at the gallery's fingertips, curators are confident that such errors are unlikely to be made again. Dating of materials is reliable, explains Ashok Roy, director of scientific research at the gallery: "I don't think one could be shown a sixteenth-century picture and think it is a nineteenth- or a fourteenthcentury picture." However, the identity of the artist remains harder to settle.

An arresting example of the team's work is Caspar David Friedrich's Winter Landscape. During the Second World War, a version of this painting — known to have been created in 1811 - was found and passed on to the Museum of Art and Cultural History in Dortmund, Germany. When a similar snowy scene was acquired by the National Gallery in 1987, the question arose as to which was the original.

Both canvases were scanned with infrared light to peer beneath the surface paint layers. The resulting infrared reflectogram of the be a genuine Raphael. The exhibition also highlights how advances in digital technology are helping conservators around the world to share information and to work on larger research projects. Roy and his team hope to apply the scientific methods developed in their lab to every painting the gallery holds - a task that could take decades. As well as rooting out any remaining fakes hiding in the vaults, such records may alter art history.

Questions remain about the value attached to an artwork's authenticity. Some gallery staff admit that they still appreciate works that have been outed as attempts to deceive. If a painting is good enough to pass as a Raphael, does it matter that it isn't?

For Roy, as a scientist, the answer is clear: "We're keen to know what things are. The ultimate reason for that is to present them in an honest way to the public so they're not misled." Daniel Cressey is a reporter for Nature. 